Original Article

\title{
Efficiency of exogenous zinc sulfate application reduced fruit drop and improved antioxidant activity of 'Kinnow' mandarin fruit
}

\author{
A eficiência da aplicação de sulfato de zinco exógeno reduziu a queda da fruta e \\ melhorou a atividade antioxidante da tangerina 'Kinnow'
}

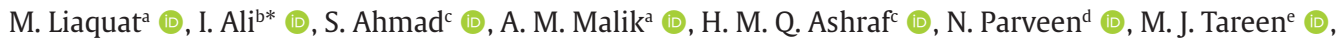 \\ T. Saeed ${ }^{\mathrm{f}}$ (D) S. H. Shah ${ }^{\mathrm{g}}$ (D) and B. Zulfiqar ${ }^{\mathrm{h}}$ (D) \\ aPMAS Arid Agriculture University, Institute of Hydroponic Agriculture, Rawalpindi, Pakistan \\ 'PPMAS-Arid Agriculture University, Deparment of Horticulture, Rawalpindi, Pakistan \\ cUniversity of Agriculture, Institute of Horticultural Sciences, Faisalabad, Pakistan \\ dUniversity of Agriculture, Department of Plant Breeding and Genetics, Faisalabad, Pakistan \\ ${ }^{\mathrm{e}}$ Agriculture Research Institute, Balochistan, Pakistan \\ fGovernment of Azad Jammu and Kashmir, Department of Agriculture, Muzaffarabad, Pakistan \\ ${ }^{g}$ Allama Iqbal Open University, Faculty of Sciences, Department of Agricultural Sciences, Islamabad, Pakistan \\ ${ }^{\text {hS}}$ Scientific Officer Horticulture Soil and Water Conservation Research Institute, Chakwal, Pakistan
}

\begin{abstract}
'Kinnow' mandarin (Citrus nobilis L.× Citrus deliciosa T) is an important marketable fruit of the world. It is mainstay of citrus industry in Pakistan, having great export potential. But out of total production of the country only $10 \%$ of the produce meets the international quality standard for export. Pre-harvest fruit drop and poor fruit quality could be associated with various issues including the plant nutrition. Most of the farmers do not pay attention to the supply of micro nutrients which are already deficient in the soil. Furthermore, their mobility within plants is also a question. Zinc ( $\mathrm{Zn}$ ) is amongst those micronutrients which affect the quality and postharvest life of the fruit and its deficiency in Pakistani soils is already reported by many researchers. Therefore, this study was carried out to evaluate the influence of pre-harvest applications of zinc sulfate $\left(\mathrm{ZnSO}_{4}, 0,0.4 \%, 0.6 \%\right.$ or $\left.0.8 \%\right)$ on pre-harvest fruit drop, yield and fruit quality of 'Kinnow' mandarin at harvest. The treatments were applied during the month of October i.e. 4 months prior to harvest. The applied $\mathrm{Zn}$ sprays had significant effect on yield and quality of the "Kinnow" fruit. Amongst different foliar applications of $\mathrm{ZnSO}_{4}$ applied four months before harvest, $0.6 \% \mathrm{ZnSO}_{4}$ significantly reduced pre-harvest fruit $\operatorname{drop}(10.08 \%)$ as compared to untreated control trees (46.45\%). Similarly, the maximum number of fruits harvested per tree (627), fruit weight (192.9 g), juice percentage (42.2\%), total soluble solids ( $9.5^{\circ} \mathrm{Brix}$ ), ascorbic acid content (35.5 mg $100 \mathrm{~g}^{-1}$ ) and sugar contents (17.4) were also found significantly higher with $0.6 \% \mathrm{ZnSO}_{4}$ treatment as compared to rest of treatments and control. Foliar application of $0.6 \% \mathrm{ZnSO}_{4}$ also significantly improved total antioxidants (TAO) and total phenolic contents (TPC) in fruit. In conclusion, foliar spray of $\mathrm{ZnSO}_{4}(0.6 \%)$ four months prior to harvest reduced pre-harvest fruit drop, increase yield with improved quality of 'Kinnow' mandarin fruit.
\end{abstract}

Keywords: zinc sulfate, foliar application, fruit drop, yield, quality, antioxidants.

\begin{abstract}
Resumo
A tangerina 'Kinnow' (Citrus nobilis L. × Citrus deliciosa T.) é uma importante fruta comercializável do mundo. É o esteio da indústria cítrica no Paquistão, com grande potencial de exportação. Mas, da produção total do país, apenas $10 \%$ da produção atendem o padrão internacional de qualidade para exportação. A queda da fruta antes da colheita e a baixa qualidade da fruta podem estar associadas a vários problemas, incluindo a nutrição da planta. A maioria dos agricultores não se preocupa com o fornecimento de micronutrientes que já são deficientes no solo. Além disso, sua mobilidade dentro das plantas também é uma questão. $\mathrm{O}$ zinco ( $\mathrm{Zn}$ ) está entre os micronutrientes que afetam a qualidade e a vida pós-colheita da fruta, e sua deficiência em solos paquistaneses já é relatada por diversos pesquisadores. Portanto, este estudo foi realizado para avaliar a influência da aplicação pré-colheita de sulfato de zinco $\left(\mathrm{ZnSO}_{4} ; 0,0,4 \%, 0,6 \%\right.$ ou $0,8 \%$ ) na queda dos frutos na pré-colheita, produtividade e qualidade dos frutos da tangerina 'Kinnow' em colheita. Os tratamentos foram aplicados durante o mês de outubro, ou seja, 4 meses antes da colheita. As pulverizações de Zn aplicadas tiveram efeito significativo no rendimento e na qualidade
\end{abstract}

*e-mail: arid132@uaar.edu.pk

Received: October 15, 2020 - Accepted: January 20, 2021

This is an Open Access article distributed under the terms of the Creative Commons Attribution License, which permits unrestricted use, distribution, and reproduction in any medium, provided the original work is properly cited. 
da fruta 'Kinnow'. Entre as diferentes aplicações foliares de $\mathrm{ZnSO}_{4}$ efetuadas quatro meses antes da colheita, $0,6 \%$ de $\mathrm{ZnSO}_{4}$ reduziu significativamente a queda de frutos antes da colheita (10,08\%) em comparação com as árvores de controle não tratadas (46,45\%). Da mesma forma, número máximo de frutos colhidos por árvore (627), peso do fruto (192,9 g), porcentagem de suco (42,2\%), sólidos solúveis totais (9,5 ${ }^{\circ}$ Brix), teor de ácido ascórbico $\left(35,5 \mathrm{mg} / 100 \mathrm{~g}^{-1}\right)$ e os teores de açúcar $(17,4)$ também foram significativamente maiores com o tratamento com $0,6 \%$ de $\mathrm{ZnSO}_{4}$ em comparação com o restante dos tratamentos e o controle. A aplicação foliar de $0,6 \%$ de $\mathrm{ZnSO}_{4}$ também melhorou significativamente os antioxidantes totais (TAO) e os teores fenólicos totais (TPC) nas frutas. Em conclusão, a pulverização foliar de $\mathrm{ZnSO}_{4}(0,6 \%)$ quatro meses antes da colheita reduziu a queda de frutos antes da colheita e aumentou o rendimento com a melhoria da qualidade da fruta tangerina 'Kinnow'.

Palavras-chave: sulfato de zinco, aplicação foliar, queda do fruto, rendimento, qualidade, antioxidantes.

\section{Introduction}

Citrus is the most widely cultivated fruit crop and ranks first in the world fruits production. Total production of world citrus industry possesses 12,257 thousand tons with an area of 8712 thousand ha. Currently in Pakistan different citrus fruits are planted on an area of 206,569 ha and the production in 2016 was 2.36 million tons. Currently, leading citrus-producing countries in the world are Brazil, China, United States, Mexico, India and Spain which contribute about 2/3 of worldwide citrus production (FAO, 2017).

Citrus fruits comprise multiple of vitamins, minerals, fiber and phytochemicals such as carotenoids, flavonoids, and limonoids which are helpful for human health. Citrus fruit has antioxidant, anti-mutagenic properties. Due to these phyto-nutritional properties citrus fruit is considered to have positive relationship with bone health, reduce risk of cardiovascular disease and builds-up strong immune system (Codoner-Franch and Valls-Belles, 2010). 'Kinnow' mandarin is one of the very famous cultivars of citrus known for its unique taste and quality. The climate in Pakistan provides suitable conditions for the cultivation of 'Kinnow' mandarin. However, citrus crop suffers serious issues such as poor fruit quality (deteriorated fruit color, small size) and substantial pre-harvest fruit drop due to lack of essential macro and micronutrients in soils (Ibrahim et al., 2007).

Fruit drop is a serious issue faced by citrus growers as it started from flowering and continues until harvest (Modise et al., 2009). The pre-harvest fruit drop has become a recognized problem for citrus growers for many years (Modise et al., 2009; Omaima and El-Metwally, 2007). The shedding and falling of mature fruit is a huge loss for orchardists. Factors that cause the drop of fruit prematurely include high temperatures, inadequate water supply, wind, insect-pest, disease attacks and lack of nutrients (Razi et al., 2011).It is reported that inappropriate use of growth regulators such as auxins, cytokinins and gibberellins, the abscission layer is formed on the stem which leads to increase in fruit drop (Balal et al., 2011; Chen and Dekkers, 2006; Lahey et al., 2004). Another major reason of fruit drop is improper use of nutrients (Saleem et al., 2005).

Applications of growth regulators or nutrients have been reported to reduce the intensity of pre-harvest fruit drop in citrus (Ashraf et al., 2012). Zinc (Zn) is a vital micronutrient among the different necessary mineral nutrient which is required for proper activity of various enzymes, synthesis of proteins and carbohydrates (Broadley et al., 2007). $\mathrm{Zn}$ is also involved in the synthesis of tryptophan, which is a precursor of indole acetic acid (IAA). Similarly, $\mathrm{Zn}$ has a pivotal role as a cofactor in enzyme activities in starch metabolism (Alloway, 2008). Pakistani soils are $\mathrm{Zn}$ deficient due to higher $\mathrm{pH}$ (Rashid and Ryan, 2004). Zn spray applied as foliar spray can minimize the deficiency better as compared to soil application. Due to lesser mobility in the soils the soil applied zinc is not fully available to the plants. Furthermore, foliar sprays of $\mathrm{Zn}$ are effective because it is environmentally non-toxic (El-Aal et al., 2010; Zodape et al., 2011).

$\mathrm{Th}$ e eff i c a c y of f o l i a r

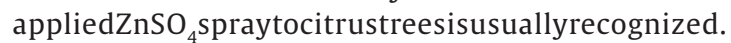
However, to the superlative of our information very little is known in the literature regarding the efficiency of foliar applied $\mathrm{ZnSO}_{4}$ on growth and quality-related parameters such as level of antioxidants, antioxidative enzymes such as catalase (CAT), peroxidase (POD) and superoxide dismutase (SOD) enzymes in 'Kinnow' mandarin fruit. Therefore, the purpose of this study was to examine the effectiveness of foliar-applied $\mathrm{ZnSO}_{4}$ in reducing pre-harvest drop and improving quality-related attributes of 'Kinnow' mandarin fruit in Pakistan.

\section{Materials and Methods}

\subsection{Plant materials and growing conditions}

Commercially cultivated ten-year-old healthy and uniform disease free mandarin cv. 'Kinnow' (Citrus nobilis L. $\times$ Citrus deliciosa T) trees grown at the Experimental Fruit Orchard Square No. 9, (31 $\left.{ }^{\circ} 25^{\prime} \mathrm{N} ; 7^{\circ} 09^{\prime} \mathrm{E}\right)$, Institute of Horticultural Sciences, University of Agriculture, Faisalabad, Pakistan were chosen for this study. An experimental unit was considered as a single tree with four replicates so a total of sixteen trees were under observation in the experiment. Nitrogen, phosphorus and potassium (NPK) was applied at the rate of $1200 \mathrm{~g}, 600 \mathrm{~g}, 600$ grespectively to all trees. Full doses of $\mathrm{P}$ and $\mathrm{K}$ with half dose of $\mathrm{N}$ were applied on $15^{\text {th }}$ February (before flowering) and $2^{\text {nd }}$ half dose of $\mathrm{N}$ was applied on $15^{\text {th }}$ April (after fruit setting). In the last week of October, the selected trees were sprayed with different doses of $\mathrm{ZnSO}_{4}(0.4 \%, 0.6 \%$ and $0.8 \%)$ and the fruits were harvested at the end of January when it was commercially mature. Tween 20 (0.01\%) as a wetting agent was added for the foliar spray. By using manual sprayer foliar application was carried out in the morning and all the trees were thoroughly covered with spray till run-off. The control trees were sprayed with distilled water only. 
Following parameters were recorded to check the effect of treatments;

\subsection{Pre-harvest fruit drop}

The fruit drop (\%) was measured according to Khan et al. (2009) from the tagged branches from four sides of the plant by calculating the number of fruit per branch at the two-day interval and at later one-month interval using the following Formula 1:

$$
\text { Fruit drop } \%=\frac{\text { Total fruit drop }}{\text { Total fruit set }} \times 100
$$

\subsection{Fruit number and yield per tree}

It was counted on $24^{\text {th }}$ December. To accurately assess the number of fruit, a small quantity of $\mathrm{CaCO}_{3}$ mixture (lime) was prepared in water just to identify the branches and the bamboo sticks fixed with fine cotton cloth were immersed in the $\mathrm{CaCO}_{3}$ mixture to mark the fruit number. The average weight of the fruit was multiplied by total fruit number to calculate the total yield per tree.

\subsection{Fruit weight, peel and pulp weight, peel to pulp ratio and juice contents (\%)}

Ten fruits were selected weighing on a digital weighing balance. The total weight of the fruit was divided by the fruit number to get average fruit weight. The fruit peel was removed by hand and the peel weight was taken. The average pulp content was estimated by means of subsequent Formula 2:

$$
\text { Pulp weight }(\%)=\frac{\text { Pulp weight average }}{\text { Fruit weight average }} \times 100
$$

Peel to pulp ratio was estimated by dividing the peel by the subsequent value of the pulp.

'Kinnow' fruit Juice sample (10 fruit) was extracted and weighed to estimate the fruit juice (\%) by means of subsequent Formula 3:

$$
\text { Juice Contents }(\%)=\frac{\text { Juice weight average }}{\text { fruit weight average }} \times 100
$$

\subsection{Total Soluble Solid (TSS) and Titratable Acidity (TA)}

By using a refractometer (RX 5000, Atago, Japan), the content of TSS in the juice was assessed. The TA of the juice was calculated using the process described by Khan et al. (2009). By using 2-3 drops of phenolphthalein as an indicator, TA was determined by titrating $5 \mathrm{~mL}$ of juice and using $0.1 \mathrm{~N}$ sodium hydroxide (Formula 4 ).

$$
\mathrm{TA}(\%)=\frac{0.1 \mathrm{~N} \mathrm{NaOH} \times 0.0064 \times 100}{\text { Fruit juice used }(\mathrm{ml})}
$$

\subsection{Ascorbic acid contents}

It was estimated according to the titration process defined by AOAC (2000). Take Five $\mathrm{mL}$ of frozen fruit juice into a $100 \mathrm{~mL}$ volumetric flask and make up to volume by adding $0.4 \%$ oxalic acid solution. Take Out from these $5 \mathrm{~mL}$ filtrated aliquot and titrated against 2, 6-dichlorophenolindophenol dye to the end of the light pink colour for at least $15 \mathrm{sec}$ and was expressed as mg $100 \mathrm{~g}^{-1} \mathrm{FW}$.

\subsection{Sugar contents}

The sugar contents in the juice were determined by using the process Khan et al. (2009). A juice sample $(10 \mathrm{~mL})$ taken from a $250 \mathrm{~mL}$ volumetric flask was mixed with $25 \mathrm{~mL}$ lead acetate solution (25\%) and $10 \mathrm{~mL}$ potassium oxalate (20\%) and the volume was prepared $100 \mathrm{~mL}$ by mixing distilled water. The filtrate was used to estimate several forms of sugars. The titration method was used for the measurement of sugar content. By using the following Formulas 5 to 7 the values were calculated.

$$
\begin{aligned}
& \text { Total sugars }=25 \times\left(\frac{\mathrm{X}}{\mathrm{Z}}\right) \\
& \text { Reducing sugars }=6.25 \times\left(\frac{x}{\mathrm{Y}}\right) \\
& \text { Non reducing sugar }=0.95 \times(\text { total sugars } \%-\text { reducing sugars } \%)
\end{aligned}
$$

$\mathrm{X}=$ standard sugar solution volume $(\mathrm{mL})$ titrated against 10 mL Fehling's solution;

$\mathrm{Y}=$ sample aliquot volume $(\mathrm{mL})$ used against $10 \mathrm{~mL}$ Fehling's solution;

$\mathrm{Z}=$ sample aliquot volume $(\mathrm{mL})$ titrated against $10 \mathrm{~mL}$ of Fehling's solution.

\subsection{Total antioxidants (TAO) and total phenolics (TPC)}

TAO in the 'Kinnow' fruit juice was determined by Mimica-Dukic et al. (2003), using 2, 2-diphenyl-1picrylhydrazyl radical (DPPH) assay. The DPPH solution (0.004\% methanol) was mixed with supernatant (50 $\mu \mathrm{l})$ in the microtubes and incubated in the darkness. Folin-Ciocalteu was used to determine the TPC of 'Kinnow' fruit by technique as described by Ainsworth and Gillespie (2007). The results of TPC (mg GAE $100 \mathrm{~g}^{-1}$ ) and total antioxidants (\% inhibition) were noted using a spectrophotometer (2-8200 Series Polarized Zeeman, Hitachi, Kyoto, Japan) at765 nm and $517 \mathrm{~nm}$ wavelength, respectively. \% DPPH Inhibition was estimated by using Formula 8:

$$
1 \%=\frac{A b-A s}{A b} \times 100
$$

$\mathrm{Ab}=$ mixture of blank

As $=$ Mixture of sample

\subsection{Enzyme assay}

After homogenization frozen juice sample ( $1 \mathrm{~g})$, using $2 \mathrm{ml}$ phosphate buffer ( $7.2 \mathrm{pH}$ ) and centrifuged at 10,000 $\mathrm{x} g$ for $5 \mathrm{~min}$ at $4{ }^{\circ} \mathrm{C}$ was used to estimate enzymatic actions of CAT, POD and SOD. Supernatant was collected and used to measure the activity of antioxidant enzymes (Liu et al., 2011). 


\section{Statistical Analysis}

Randomized Complete Block Design (RCBD) was used for this study. The Data were subjected to Analysis of Variance (ANOVA) by using Statistix ver. 8.1 (Analytical software, Tallahasee, USA) and least significant difference (LSD) test was used to compared treatment means at $P \leq 0.05$ (Steel et al., 1997).

\section{Results}

\subsection{Pre-harvest fruit drop}

It is obvious from the data that fruit drop values were affected significantly by the $\mathrm{Zn}$ sprays as compared to control. Irrespective of treatments, trees sprayed with $\mathrm{ZnSO}_{4}$ exhibited a significant reduction in pre-harvest fruit drop (Table 1). Though, all the treatments were able to reduce fruit drop significantly of "Kinnow" mandarin; however, sprays of ZnSO4 @ 0.6\% showed least fruit drop (10.08\%) followed by $\mathrm{ZnSO}_{4}$ sprays @ 0.8\% (15.03\%) and $\mathrm{ZnSO}_{4} @ 0.4 \%$ (17.69\%). The trees receiving distilled water sprays (control) exhibited highest percentage of fruit drop (46.45\%) which was 4.6 folds higher as compared to the plants treated with ZnSO4 @ 0.6\%.

\subsection{Fruit physical characteristics and yield per plant at harvest}

Number of fruit per plant, fruit weight, and juice contents were significantly affected in treated fruits as compared to untreated fruits (Table 1). Moreover, data regarding fruit number (Table 1 ) showed a significant increase in fruit number in the trees which were sprayed with different levels of $\mathrm{Zn}$ sprays. The highest values in terms of fruit number were noted in trees sprayed with $0.6 \% \mathrm{ZnSO}_{4}$ (627), which is about 1.67 -fold higher in contrast to control trees which exhibited least number of fruit (374) as compared to rest of the treatments (Table 1). It is evident from Table 1 that all the treatments were found effective in improving fruit weight significantly of "Kinnow" mandarin, yet, highest increase in fruit weight (1.21 fold) was found in the fruits obtained from the trees receiving $0.6 \% \mathrm{ZnSO}_{4}$ spray treatment four months before harvest. Furthermore, the trees treated with $0.6 \%$ $\mathrm{ZnSO}_{4}$ showed maximum juice weight 1.46 -fold more as compared to untreated trees (Table 1). Similarly, other physical characteristics of fruit i.e. peel weight, pulp weight and peel to pulp ratio were also affected significantly by the treatments. All the treatments significantly reduced these physical characters as compared to control (Table 1). Control trees exhibited about 1.33, 1.12 and 1.18 fold higher peel, pulp weight and peel to pup ratio respectively, than the fruit of trees treated with $0.6 \% \mathrm{ZnSO}_{4}$, respectively.

The effect of all the treatments of $\mathrm{ZnSO}_{4}$ on yield of "Kinnow" mandarin trees has been shown in Table 2. It is clear from the data that all of the treatments effectively increased fruit yield as compared to control. Maximum fruit yield was achieved by spraying $0.6 \% \mathrm{ZnSO}_{4}(120.89 \mathrm{Kg})$, on the other lowest fruit yield $(59.59 \mathrm{Kg})$ was recorded in the trees which did not receive any sprays of micronutrient. Correspondingly, $0.6 \% \mathrm{ZnSO}_{4}$ treated trees showed about 2.02-fold higher yield in contrast to untreated trees (Table 2). Other treatments of $\mathrm{Zn}$ as micro nutrient spray produced intermediate results.

\section{Biochemical Parameters}

Data presented in Table 3 exhibits that total soluble solid contents (TSS) of fruit juice were significantly $(P \leq 0.05)$

Table 1. Effect of exogenous $\mathrm{ZnSO}_{4}$ application on pre-harvest fruit drop.

\begin{tabular}{lcccc}
\hline \multicolumn{1}{c}{ Treatments } & $\begin{array}{c}\text { Pre-harvest fruit } \\
\text { drop }\end{array}$ & No. of fruit per tree & Fruit weight & Juice contents (\%) \\
\hline Control & $46.45 \pm 1.26 \mathrm{a}$ & $374.02 \pm 3.24 \mathrm{~d}$ & $159.32 \pm 1.68 \mathrm{~d}$ & $28.900 \pm 0.83 \mathrm{~d}$ \\
$0.4 \% \mathrm{ZnSO}_{4}$ & $17.69 \pm 0.85 \mathrm{~b}$ & $461.81 \pm 5.05 \mathrm{c}$ & $173.93 \pm 1.48 \mathrm{c}$ & $34.947 \pm 0.55 \mathrm{c}$ \\
$0.6 \% \mathrm{ZnSO}_{4}$ & $10.06 \pm 0.52 \mathrm{~d}$ & $627.03 \pm 22.41 \mathrm{a}$ & $192.91 \pm 1.08 \mathrm{a}$ & $42.230 \pm 0.97 \mathrm{a}$ \\
$0.8 \% \mathrm{ZnSO}_{4}$ & $15.03 \pm 0.56 \mathrm{c}$ & $510.61 \pm 6.86 \mathrm{~b}$ & $187.40 \pm 0.90 \mathrm{~b}$ & $38.210 \pm 0.66 \mathrm{~b}$ \\
LSD & $\mathbf{2 . 4 7}$ & $\mathbf{3 5 . 1 5}$ & $\mathbf{4 . 4 5 3 8}$ & $\mathbf{2 . 7 2}$ \\
\hline
\end{tabular}

Table 2. Effect of exogenous $\mathrm{ZnSO}_{4}$ application on peel, pulp weight and peel: pulp ratio.

\begin{tabular}{lcccc}
\hline \multicolumn{1}{c}{ Treatments } & Peel weight $(\mathrm{g})$ & Pulp weight $(\mathbf{g})$ & Peel: Pulp ratio & Yield per tree (Kg) \\
\hline Control & $42.77 \pm 0.94 \mathrm{a}$ & $29.33 \pm 0.42 \mathrm{a}$ & $1.46 \pm 0.02 \mathrm{a}$ & $59.59 \pm 0.71 \mathrm{~d}$ \\
$0.4 \% \mathrm{ZnSO}_{4}$ & $38.77 \pm 0.62 \mathrm{~b}$ & $27.54 \pm 0.42 \mathrm{~b}$ & $1.41 \pm 0.03 \mathrm{a}$ & $80.32 \pm 1.14 \mathrm{c}$ \\
$0.6 \% \mathrm{ZnSO}_{4}$ & $32.13 \pm 0.53 \mathrm{~d}$ & $26.18 \pm 0.24 \mathrm{c}$ & $1.23 \pm 0.01 \mathrm{c}$ & $120.89 \pm 3.68 \mathrm{a}$ \\
$0.8 \% \mathrm{ZnSO}_{4}$ & $35.98 \pm 0.61 \mathrm{c}$ & $26.88 \pm 0.24 \mathrm{bc}$ & $1.34 \pm 0.02 \mathrm{~b}$ & $95.69 \pm 1.43 \mathrm{~b}$ \\
LSD & $\mathbf{2 . 2 1}$ & $\mathbf{1 . 1 1}$ & $\mathbf{0 . 0 6}$ & $\mathbf{5 . 8 5}$ \\
\hline
\end{tabular}

In each column the means showed different lettersfor peel weight are significantly different from one another. Same letter means in each column are not significantly different at $P \leq 0.05$ for pulp weight and peel: pulp ratio using LSD test. 
Table 3. Effect of exogenous $\mathrm{ZnSO}_{4}$ application on TSS, TA, TSS: acid ratio, ascorbic acid contents and total sugars.

\begin{tabular}{lccccc}
\hline \multicolumn{1}{c}{ Treatments } & TSS ( $\left.{ }^{\circ} \mathbf{B r i x}\right)$ & TA (\%) & TSS: acid ratio & $\begin{array}{c}\text { Ascorbic acid } \\
\left(\mathbf{m g ~ 1 0 0 g} \mathbf{~}^{-1}\right)\end{array}$ & Total Sugars (\%) \\
\hline Control & $8.20 \pm 0.06 \mathrm{~d}$ & $0.59 \pm 0.03 \mathrm{c}$ & $14.0 \pm 0.70 \mathrm{a}$ & $28.08 \pm 0.49 \mathrm{~d}$ & $9.53 \pm 0.34 \mathrm{~d}$ \\
$0.4 \% \mathrm{ZnSO}_{4}$ & $9.06 \pm 0.02 \mathrm{c}$ & $0.78 \pm 0.02 \mathrm{a}$ & $11.68 \pm 0.27 \mathrm{~b}$ & $32.70 \pm 0.44 \mathrm{~b}$ & $12.72 \pm 0.36 \mathrm{c}$ \\
$0.6 \% \mathrm{ZnSO}_{4}$ & $9.49 \pm 0.02 \mathrm{a}$ & $0.68 \pm 0.01 \mathrm{~b}$ & $13.98 \pm 0.24 \mathrm{a}$ & $35.46 \pm 0.42 \mathrm{a}$ & $17.36 \pm 0.36 \mathrm{a}$ \\
$0.8 \% \mathrm{ZnSO}_{4}$ & $9.33 \pm 0.04 \mathrm{~b}$ & $0.73 \pm 0.02 \mathrm{ab}$ & $12.89 \pm 0.27 \mathrm{ab}$ & $31.10 \pm 0.41 \mathrm{c}$ & $14.26 \pm 0.52 \mathrm{~b}$ \\
LSD & $\mathbf{0 . 1 4}$ & $\mathbf{0 . 0 7}$ & $\mathbf{1 . 3 5}$ & $\mathbf{1 . 4 8}$ & $\mathbf{0 . 9 6}$ \\
\hline
\end{tabular}

In each column the means showed different letters forTSS and ascorbic acid contents are significantly different from one another. Same letter means in each column are not significantly different at $P \leq 0.05$ for TA and TSS: acid ratio using LSD test.

Table 4. Effect of exogenous $\mathrm{ZnSO}_{4}$ application onfruit quality enzymes and phytochemicals.

\begin{tabular}{|c|c|c|c|c|c|}
\hline Treatments & $\begin{array}{c}\text { CAT } \\
\left(\mathrm{U} \mathrm{mg}^{-1} \text { protein }\right)\end{array}$ & $\begin{array}{c}\text { SOD } \\
\left(\mathrm{U} \mathrm{mg}^{-1} \text { protein }\right)\end{array}$ & $\begin{array}{c}\text { POD } \\
\text { (U } \mathrm{mg}^{-1} \text { protein) }\end{array}$ & $\begin{array}{c}\text { Total } \\
\text { Antioxidants } \\
\text { (\% inhibition) }\end{array}$ & $\begin{array}{l}\text { Total Phenolics } \\
\left.\text { (mg GAE } 100 \mathrm{~g}^{-1} \mathrm{FW}\right)\end{array}$ \\
\hline Control & $30.83 \pm 2.53 \mathrm{a}$ & $114.51 \pm 1.11 \mathrm{a}$ & $11.40 \pm 1.01 \mathrm{a}$ & $40.32 \pm 0.30 d$ & $144.68 \pm 1.73 \mathrm{~d}$ \\
\hline $0.4 \% \mathrm{ZnSO}_{4}$ & $31.49 \pm 1.81 \mathrm{a}$ & $118.05 \pm 0.35 \mathrm{a}$ & $14.31 \pm 1.61 \mathrm{a}$ & $44.40 \pm 0.96 c$ & $173.04 \pm 1.80 \mathrm{~b}$ \\
\hline $0.6 \% \mathrm{ZnSO}_{4}$ & $32.94 \pm 0.29 a$ & $118.49 \pm 0.33 \mathrm{a}$ & $14.09 \pm 1.33 \mathrm{a}$ & $53.25 \pm 0.97 a$ & $205.32 \pm 2.15 a$ \\
\hline $0.8 \% \mathrm{ZnSO}_{4}$ & $31.27 \pm 3.32 \mathrm{a}$ & $119.12 \pm 0.24 \mathrm{a}$ & $12.93 \pm 1.26 \mathrm{a}$ & $48.51 \pm 0.65 b$ & $164.89 \pm 0.95 c$ \\
\hline LSD & 7.70 & 3.09 & 4.63 & 2.07 & 5.01 \\
\hline
\end{tabular}

Same letter means in each column for each enzymeat each concentrationare not significantly different at $P \leq 0.05$ using LSD test.

affected by foliar application of $\mathrm{ZnSO}_{4}$. All the treatments were able to increase significantly the TSS values of fruit juice as compared to control, yet, ZnSO @ 0.6\% exhibited the highest values of TSS as compared to the rest of the treatments $\left(9.49^{\circ} \mathrm{Brix}\right)$, followed by $0.8 \% \mathrm{ZnSO}_{4}$ treatment $\left(9.33^{\circ} \mathrm{Brix}\right)$ and $0.4 \% \mathrm{ZnSO}_{4}\left(9.06{ }^{\circ} \mathrm{Brix}\right)$ sprays 4 months before harvest. Fruit harvested from the trees which received only distilled water sprays as treatments (control) had least values in terms of total soluble solids ( $8.20^{\circ} \mathrm{Brix}$ ). It is obvious that foliar application of $\mathrm{ZnSO}_{4}$ was able to increase the value of TSS upto 1.16 fold than the untreated fruit (Table 3).

Concerning TA (\%) values, data in Table 3 revealed a significant increase in the acidity values by the application of different levels of $\mathrm{ZnSO}_{4}$ treatments as compared to control. Highest values of TA was observed in the fruit which received $0.4 \% \mathrm{ZnSO}_{4}$ spray treatment $(0.78 \%)$, followed by $0.8 \% \mathrm{ZnSO}_{4}$ spray treatment $(0.73)$. Both of these treatments were statistically at par but significantly better than the other treatments including control. $0.6 \% \mathrm{ZnSO}_{4}$ spray treatment though had least values of titratable acidity $(0.68 \%)$ among the different levels of $\mathrm{Zn}$, yet it proved to be better when compared with control which exhibited least value in terms of titratable acidity i.e. 0.59\% (Table 3).

Ascorbic acid values of "Kinnow" fruit juice were also affected significantly by different sprays treatments (Table 3 ). The effect of $\mathrm{Zn}$ was more pronounced when it was applied in the form of $\mathrm{ZnSO}_{4} @ 0.6 \%$ with values of $35.46 \mathrm{mg} / 100 \mathrm{FW}$, followed by $\mathrm{ZnSO}_{4} @ 0.4 \%$ (32.70 mg/100 g FW) and ZnSO @0.8\%(31.10 mg/100 g FW), while control exhibited least values in terms of ascorbic acid contents i.e. 28.08 mg/100 FW.ZnSO @ 0.6\% treated fruit had 1.26 times higher levels of ascorbic acid as compared to the fruit produced by control trees (Table 3 ).

When values of sugar contents (total sugars) of fruit juice of "Kinnow" mandarin were compared amongst the treatments, $\mathrm{Zn}$ treated fruits exhibited significantly higher values of all these sugars contents as compared to control (Table 3 ). Highest values of total sugars were obtained when the fruits were treated with $\mathrm{ZnSO}_{4} @ 0.6 \%$ before 4 months of harvest on tree (Table 3).ZnSO @ 0.6\% was able to improve the total sugar contents of the fruit juice, and 1.8 folds higher values as compared to control which exhibited least values of total sugars amongst all the treatments i.e. $9.53 \%$.

\section{Enzymatic and Non-Enzymatic Antioxidant Compounds}

Data in Table 4 reveals that enzymatic antioxidants i.e. CAT, POD and SOD were not affected significantly by different treatments. It is obvious from the data that, though non-significantly yet, the treatments were able to maintain higher levels of these enzymatic antioxidants in the fruit juice as compare to control which exhibited the least value for these enzymatic antioxidants (Table 4)

Non enzymatic antioxidants i.e. total phenolics and total antioxidants of fruit juice of "Kinnow" mandarin were affected significantly by the treatments (Table 4). All the treatments of $\mathrm{Zn}$ sprays proved to be significantly superior in improving the non-enzymatic antioxidants of fruit juice as compared to control. Though all the treatments were able to maintain higher levels of total phenolics yet, ZnSO4 @ 0.6\% proved to be statistically 
better in comparison with other treatments in improving the TPC of the fruit at harvest (Table 4). Lowest value of TPC was recorded in control (Table 4). The harvested fruit from the trees sprayed with $0.6 \% \mathrm{ZnSO}_{4}$ exhibited a highest TPC value (205.33 mg GAE100 g-1 FW) which was about 1.42-fold than the fruit which was harvested from untreated trees (Table 4).

A very similar trend for total antioxidants was observed by the treatments during the study (Table 4) where treatments had significant effect on the values of total antioxidants at harvest. An increase in total antioxidants was noted by all the treatments. Maximum value of total antioxidant was calculated in the juice obtained from the fruit which received the ZnSO4 @ 0.6\% spray treatment before harvest (53.25\%) followed by ZnSO4 @0.8\% (48.51\%) and ZnSO4 @ 0.4\% (44.40\%). Least value for total antioxidants was observed in untreated fruit (40.32\%).The fruit of trees treated with $0.6 \% \mathrm{ZnSO}_{4}$ increased total antioxidant activity of the juice by 1.32 -fold than control (Table 4).

\section{Discussion}

Based on the results of analysis of variance, general positive effects of pre-harvest treatments of Zn sprays have been observed on fruit drop and overall quality of "Kinnow" mandarin fruit. In the present studies intermediate dose of $\mathrm{ZnSO}_{4}$ i.e. $0.6 \%$ proved to be the most effective treatment in this regard.

Foliar sprays of all treatments significantly reduced the fruit drop as compared to control, $0.6 \% \mathrm{ZnSO}_{4}$ sprays proved superior in this regard as compared to rest of treatments in 'Kinnow' mandarin. Razzaq et al. (2013) reported similar results that lowest pre-harvest fruit drop, highest total fruit number and fruit weight per tree at harvest in 'Kinnow' mandarin by exogenous application of $\mathrm{ZnSO}_{4}$. Less fruit drops in all treated plants could be due to less internal ethylene synthesis because internal ethylene induces the formation of the abscission layer in pedicle fruit and stem zone. Robinson et al. (2010) stated that ethylene produces the hydrolytic (cellulase and polygalacturonase) enzymes in the cell walls which result in the separation of fruit from pedicle ultimately resulting in fruit drop. Maximum fruit retained in $\mathrm{Zn}$ treated trees can also be attributed to rise in IAA synthesis which subsequently enhances the endogenous levels of auxins, subsequently inhibiting ethylene synthesis in the abscission zone to prevent fruit drop (Goren et al., 2000). Similar results were reported by Venu et al. (2014) who explained that $\mathrm{Zn}$ plays a significant role in the synthesis of auxin, leading to better photosynthesis, more starch accumulation in fruits and the auxin producing stability in the plant, which control the fruit drop and increased total fruit number per tree.

Foliar application of $\mathrm{ZnSO}_{4}$ significantly improved fruit physical characteristics likefruit weight, fruit juice percentage, peel weight, pulp weight, peel: pulp ratio and yield. This may result in greater price in the market, since yield is directly proportional to prices of the commodity in the market. Previous studies has also confirmed that the exogenousZnSO $\mathrm{Sp}_{4}$ application increased fruit physical and biochemical quality parameters of 'Kinnow', 'Khasi' mandarin and of Washington Navel' oranges fruit (Babu and Yadav, 2005; Hafez and El- Metwally, 2007; Eman et al., 2007). This might be attributed to $\mathrm{Zn}$ function in the synthesis of tryptophan which is a precursor of IAA synthesis which takes part in fruit growth and development. Hence, more $\mathrm{Zn}$ in the leaves helps producing more tryptophan resulting in enhancement inthe fruit growth and quality.It is recognized that $\mathrm{Zn}$ is involved in many physiological functions of plants which are involved in quality and yield of the crop. Foliar spray of $\mathrm{ZnSO}_{4}$ was found most effective for improving the physico-chemical quality-related parameters of guava fruit at harvest (Hafeez et al., 2013; Goswami et al., 2012).Concurrently, the foliar Zn spray on tree yield might be ascribed to improved endogenous auxin levels resulting in the improved fruit set. Theyield of 'Kinnow' mandarin trees was higher obtained by exogenous $\mathrm{ZnSO}_{4}$ application due to enhance in both the fruit number per tree and fruit weight (Rawat et al., 2010). Abd El Moneim et al. (2007) stated that use of $0.6 \% \mathrm{ZnSO}_{4}$ alone or with gibberellic acid $\left(\mathrm{GA}_{3}\right)$, in particular at $20 \mathrm{ppm}$, in addition to the physical and chemical appearance of the fruit, significantly increases fruit retention and reduced fruit drop, thereby increasing yield.

Fruit quality is one of the important factors affecting export of citrus (Deng, 1996).The general positive effects observed during this study on fruit quality parameters like TSS, titratable acidity, sugars, enzymatic and nonenzymatic antioxidants of "Kinnow" mandarin as a result of $\mathrm{ZnSO}_{4}$ application could be attributed to its influence on specific enzymes that take part within the development of sugars, acids and proteins. Dutta and Banik (2007) stated that the exogenous application of $\mathrm{ZnSO}_{4}$ improved the internal physiology of developing fruit for their suitable growth and development. Dawood et al. (2001) stated that pre-harvest spray of $\mathrm{Zn}$ was found to enhance vitamin $\mathrm{C}$ contents of juice in many citrus cultivars. Nawaz et al. (2008) mentioned that the $\mathrm{Zn}$ performs a significant function in the auxin synthesis and enhance vitamin $C$ accumulation in 'Kinnow' mandarin. Likewise, vitamin C content increased in 'Kinnow' mandarin due to exogenous spray application of $\mathrm{Zn}$ (Trivedi et al., 2012). Similar results were stated by Khan et al. (2012) that foliar spray of $\mathrm{ZnSO}_{4}$ enhanced vitamin C contents in the Feutrell's early fruit juice. The increase in sugars levels could be ascribed due to the influence of $\mathrm{Zn}$ on the aldolase enzyme activities that perform an essential function in the sugar formation (Alloway, 2008). Zn treatment also enhanced the total sugar contents of 'Khasi' mandarin fruit (Babu and Yadav, 2005). Likewise, TAO and TPC contents were improved by foliar spray of $\mathrm{ZnSO}_{4}$ in many fruits (Song et al., 2015; Khan et al., 2015; Jan and Hadi, 2015).

\section{Conclusion}

It is concluded that $0.6 \% \mathrm{ZnSO}_{4}$ as a foliar spray four months before harvesting reduced pre-harvest fruit drop, increased yield and improved the TAO, 
TPC activities and other quality-related parameters of 'Kinnow' mandarin.

\section{Acknowledgements}

The authors thankfully acknowledge the Institute of Horticultural Sciences, University of Agriculture, Faisalabad, Pakistan, for providing logistical support and analytical facilities and fruit quality analysis was performed in Biochemistry Laboratory, University of Agriculture, Faisalabad. This research article was collected from $\mathrm{PhD}$ study of the first author.

\section{References}

ABD EL MONEIM, A., EMAN, A., ABDELMIGEED, M.M.M. and OMAYMA, M.M.I., 2007. GA3 and zinc sprays for improving yield and fruit quality of Washington navel orange trees grown under sandy conditions. Research Journal of Agriculture and Biological Sciences, vol. 3, no. 5, pp. 498-503.

AINSWORTH, E.A. and GILLESPIE, K.M., 2007. Estimation of total phenolic content and other oxidation substrates in plant tissues using Folin-Ciocalteu reagent. Nature Protocols, vol. 2, no. 4, pp. 875-877. http://dx.doi.org/10.1038/nprot.2007.102. PMid:17446889.

ALLOWAY, B.J., 2008. Zinc in soils and crop nutrition. Brussels: The International Zinc Associationand International Fertilizer Industry Association, pp. 23-26.

ASHRAF, M.Y., YAQUB, M., AKHTAR, J., KHAN, M.A., ALI-KHAN, M. and EBERT, G., 2012. Control of excessive fruit drop and improvement in yield and juice quality of 'Kinnow' (Citrus deliciosa $\times$ (itrus nobilis) through nutrient management. Pakistan Journal of Botany, vol. 44, pp. 259-265.

ASSOCIATION OF OFFICIAL ANALYTICAL CHEMISTS - AOAC, 2000. Vitamins and other nutrients: official methods of analysis. 17th ed. Washington, D.C.: AOAC, pp. 16-20, chap. 45.

BABU, K.D. and YADAV, D.S., 2005. Foliar spray of micronutrients for yield and quality improvement in Khasi mandarin (Citrus reticulata Blanco.). Indian Journal of Horticulture, vol. 62, pp. 280-281.

BALAL, R.M., ASHRAF, M.Y., KHAN, M.M., JASKANI, M.J. and ASHFAQ M., 2011. Influence of salt stress on growth and biochemical parameters of citrus rootstocks. Pakistan Journal of Botany, vol. 43, pp. 2135-2141.

BROADLEY, M.R., WHITE, P.J., HAMMOND, J.P., ZELKO, I. and LUX, A., 2007. Zinc in plants. The New Phytologist, vol. 173, no. 4, pp. 677-702. http://dx.doi.org/10.1111/j.1469-8137.2007.01996.x. PMid:17286818.

CHEN, H.Q. and DEKKERS, K.L., 2006. Evaluation of growth regulator inhibitors for controlling post bloom fruit drop of citrus induced by the fungus Colletotrichumacutatum. Horticultural Science, vol. 41, pp. 1317-1321.

CODONER-FRANCH, P. and VALLS-BELLES, V., 2010. Citrus as functional foods. Current Topics in Nutraceutical Research, vol. 8, no. 4, pp. 173-183.

DAWOOD, S.A., MELIGY, M.S. and EL-HAMADY, M.M., 2001. Influence of zinc sulfate application on tree leaf and fruit characters of three young citrus varieties grown on slightly alkaline soil. Annals of Agricultural Science, vol. 39, pp. 433-447.

DENG, X.X., 1996. Report on the eighth international convocation of citrus. Fruits Science, vol. 13, no. 4, pp. 265.
DUTTA, P. and BANIK, A.K., 2007. Effect of foliar feeding of nutrients and plant growth regulators on physico-chemical quality of sardar guava grown in red and lateritic tract of West Bengal. Acta Horticulturae, no. 735, pp. 407-411. http://dx.doi.org/10.17660/ ActaHortic.2007.735.57.

EL-AAL, F.S.A., SHAHEEN, A.M., AHMED, A.A. and MAHMOUD, A.R., 2010. Effect of foliar application of urea and amino acids mixtures as antioxidants on growth, yield andcharacteristics of squash. Research Journal of Agriculture and Biological Sciences, vol. 6 , no. 5, pp. 583-588.

EMAN, A.A., EL-MONEIM, A., ABDEL-MIGEED, M.M.M., OMAYMA, A. and ISMAIL, V., 2007. GA3 and zinc sprays for improving yield and fruit quality of Washington Navel orange trees grown under sandy soil conditions. Research Journal of Agriculture and Biological Sciences, vol. 3, pp. 498-503.

FOOD AND AGRICULTURAL ORGANIZATION OF UNITED NATIONS FAO, 2017 [viewed 15 October 2020]. FAOSTAT [online]. Rome. Available from: http:/www.faostat.fao.org/site/342/default.aspx

GOREN, R., HUBERMAN, M. and ZHONG, G.Y., 2000. Basics aspects of hormonal control of abscission. Proceedings International Society of Citriculture, vol. 9, pp. 591-594.

GOSWAMI, A.K., SHUKLA, H.S., KUMAR, P. and MISHRA, D.S., 2012. Effect of pre harvest application of micro-nutrients on quality of guava (Psidiumguajava L.) Cv. Sardar. HortFlora Research Spectrum, vol. 1, no. 1, pp. 60-63.

HAFEEZ, B., KHANIF, Y.M. and SALEEM, M., 2013. Role of zinc in plant nutrition a review. American Journal of Experimental Agriculture, vol. 3, no. 2, pp. 374-391. http://dx.doi.org/10.9734/ AJEA/2013/2746.

HAFEZ, M.O. and EL-METWALLY, I.M., 2007. Efficiency of zinc and potassium sprays alone or in combination with some weed control treatments on weeds growth, yield and fruit quality of Washington navel orange orchards. Journal of Applied Sciences Research, vol. 3, pp. 613-621.

IBRAHIM, M., AHMAD, N., ANWAR, S.A. and MAJEED, T., 2007. Effect of micronutrients on citrus fruit yield growing on calcareous soils. In: X.U. FANGSEN, H.E. GOLDBACH, P.H. BROWN, R.W. BELL, T. FUJIWARA, S. HUNZT, C.D. GOLDBERG and L. SHI, eds. Advances in plant and animal Boron nutrition. Netherlands: Springer, pp. 179-182. http://dx.doi.org/10.1007/978-1-4020-5382-5_18.

JAN, A.U. and HADI, F., 2015. Potassium, zinc and gibberellic acid foliar application enhanced salinity stress tolerance, proline and total phenolic contents in sunflower (Helianthus annuus L.). American-Eurasian Journal of Agricultural \& Environmental Sciences, vol. 15, pp. 1835-1844.

KHAN, A.S., MALIK, A.U., PERVEZ, M.A., SALEEM, B.A., RAJWANA, I.A., SHAHEEN, I.A. and ANWAR, R., 2009. Foliar application of low- biuret urea and fruit canopy position in the tree influence the leaf nitrogen status and physico-chemical characteristics of 'Kinnow' mandarin (Citrus reticulate Blanco). Pakistan Journal of Botany, vol. 41, no. 1, pp. 73-85.

KHAN, A.S., NASIR, M., MALIK, A.U., BASRA, S.M.A. and JASKANI, M.J., 2015. Combined application of boron and zinc influence the leaf mineral status, growth, productivity and fruit quality of 'Kinnow' mandarin. Journal of Plant Nutrition, vol. 38, no. 6, pp. 821-838. http://dx.doi.org/10.1080/01904167.2015.1009100.

KHAN, A.S., WASEEM, U.M., RASHID, A.U., AHMAD, S.B.A. and RAJWANA, I.A., 2012. Exogenous applications of boron and zinc influence leaf nutrient status, tree growth and fruit quality of Feutrell's Early (Citrus reticulata Blanco). Pakistan Journal of Agricultural Sciences, vol. 49, pp. 113-119.

LAHEY, K.A., YUAN, R., BURNS, J.K., UENG, P.P., TIMMER, L.W. and CHUNG, K.-R., 2004. Induction of phytohormones and 
differential gene expression in citrus flowers infected by the fungus Colletotrichumacutatum. Molecular Plant-Microbe Interactions, vol. 17, no. 12, pp. 1394-1401. http://dx.doi. org/10.1094/MPMI.2004.17.12.1394. PMid:15597745.

LIU, X., WANG, L., LIU, L., GUO, Y. and REN, H., 2011. Alleviating effect of exogenous nitric oxide in cucumber seedling against chilling stress. African Journal of Biotechnology, vol. 10, pp. 4380-4386.

MIMICA-DUKIC, N., BOZIN, B., SOKOVIĆ, M., MIHAJLOVIĆ, B. and MATAVULJ, M., 2003. Antimicrobial and antioxidant activities of three Mentha species essential oils. Planta Medica, vol. 69 , no. 5, pp. 413-419. http://dx.doi.org/10.1055/s-2003-39704. PMid:12802721.

MODISE, D.M., LIKUKU, A.S., THUMA, M. and PHUTI, R., 2009. The influence of exogenously applied 2, 4-dichlorophenoxyacetic acid on fruit drop and quality of navel oranges (Citrus sinensis L.). African Journal of Biotechnology, vol. 8, pp. 2131-2137.

NAWAZ, M.A., AHMAD, W., AHMAD, S. and KHAN, M.M., 2008. Role of growth regulators on preharvest fruit drop, yield and quality in 'Kinnow' mandarin. Pakistan Journal of Botany, vol. 40, no. 5, pp. 1971-1981.

OMAIMA, M.H. and EL-METWALLY, I.M., 2007. Efficiency of zinc and potassium spray alone or in combination with some weed control treatments on weed growth yield and fruit quality of Washington navel oranges. Journal of Applied Sciences Research, vol. 3, pp. 613-621.

RASHID, A. and RYAN, J., 2004. Micronutrients constraints to crop production in soils with Mediterranean-type characteristics. Journal of Plant Nutrition, vol. 27, no. 6, pp. 959-975. http:// dx.doi.org/10.1081/PLN-120037530.

RAWAT, V., TOMAR, Y.K. and RAWAT, J.M.S., 2010. Influence of foliar application of micronutrients on the fruit quality of guava cV. Lucknow-49. Journal of Hill Agriculture, vol. 1, no. 1, pp. 63-66.

RAZI, M.F.D., KHAN, I.A. and JASKANI, M.J., 2011. Citrus plant nutritional profile in relation to Huanglongbing prevalence in Pakistan. Pakistan Journal of Agricultural Sciences, vol. 48, no. 4, pp. 299-304.
RAZZAQ, K., KHAN, A.S., MALIK, A.U., SHAHID, M. and ULLAH, S., 2013. Foliar application of zinc influences the leaf mineral status, vegetative and reproductive growth, yield and fruit quality of 'Kinnow' mandarin. Journal of Plant Nutrition, vol. 36, no. 10, pp. 1479-1495. http://dx.doi.org/10.1080/01904167.2013.785567.

ROBINSON, T., HOYING, S., IUNGERMAN, K. and VIKLYS, K., 2010. Retain combined with NAA controls pre-harvest drop of McIntosh apples better than either chemical alone. New York Fruit Quart, vol. 18, no. 3, pp. 9-13.

SALEEM, B.A., ZIAF, K., FAROOQ M. and AHMED, W., 2005. Fruit set and drop patterns as affected by type and dose of fertilizer application in mandarin cultivars (Citrus reticulate Blanco.). International Journal of Agriculture and Biology, vol. 7, no. 6, pp. 962-965.

SONG, C.Z., LIU, M.Y., MENG, J.F., CHI, M., XI, Z.M. and ZHANG, Z.W., 2015. Promoting effect of foliage sprayed zinc sulfate on accumulation of sugar and phenolics in berries of Vitisvinifera Cv. Merlot growing on zinc deficient soil. Molecules (Basel, Switzerland), vol. 20, no. 2, pp. 2536-2554. http://dx.doi. org/10.3390/molecules20022536. PMid:25648596.

STEEL, R.G.D., TORRIE, J.H. and DICKEY, D.A., 1997. Principles and procedures of statistics: a biochemical approach. New York: McGraw Hill Book International Co.

TRIVEDI, N., SINGH, D., BAHADUR, V., PRASAD, M. and COLLIS, J.P., 2012. Effect of foliar application of zinc and boron on yield and fruit quality of guava (Psidiumguajava L.). HortFlora Research Spectrum, vol. 1, no. 3, pp. 281-283.

VENU, A., DELVADI, D.V., SHARMA, L.K., GARDWAL, P.C. and MAKHMALE, S., 2014. Effect of micronutrient application on flowering, fruiting and yield of Acid lime (Citrus aurantifolia L.)"Kagzi lime. International Journal of Tropical Agriculture, vol. 32, no. 3-4, pp. 3-4.

ZODAPE, S.T., GUPTA, A., BHANDARI, S.C., RAWAT, U.S., CHAUDHRY, D.R., ESWARAN, K. and CHIKARA, J., 2011. Foliar application of seaweed sap as biostimulant for enhancement of yield and quality of tomato (Lycopersiconesculentum Mill.). Journal of Scientific and Industrial Research, vol. 70, no. 3, pp. 215-219. 